\title{
Implementation of an eco-hydrological classification in Chilean rivers
}

\section{Implementación de una clasificación eco-hidrológica para los ríos de Chile}

\author{
Matías Peredo-Parada ${ }^{1 *}$, Francisco Martínez-Capel ${ }^{2}$, Diana I. Quevedo 3 \& Aina B. Hernández- \\ MASCARELL ${ }^{2}$ \\ ${ }^{1}$ Plataforma de Investigación en Ecohidrología y Ecohidráulica (EcoHyd). Santiago. Chile. \\ ${ }^{2}$ Instituto para la Investigación y Gestión Integrada de Zonas Costeras (IGIC). E.P.S. de Gandía. Universidad Politécnica de \\ Valencia. España. \\ ${ }^{3}$ Departamento de Ingeniería en Obras Civiles. Facultad de Ingeniería. Universidad de Santiago. Santiago. Chile. \\ *E-mail: matias.peredo@ecohyd.com
}

\begin{abstract}
Concern has grown in Chile to protect and conserve aquatic ecosystems taking into account the high degree of habitat degradation. As a first step towards the development of conservation plans, it is necessary to classify these ecosystems in order to learn about them and understand their different types and functions. Considering that hydrological regime is the main factor in the composition of river ecosystems, an Eco-Hydrological Classification of Chilean Rivers (REC-Chile) has been developed. REC-Chile is based on the hierarchical superposition of the controlling factors of the hydrological pattern in Chile. REC-Chile is a multi-scale classification system, allowing to represent different river patterns at different spatial scales according to the selected controlling factors. The typology of the river segment is represented as a 6-digit code, in which the position of the digit represents the controlling factor and the digit value represents the factor category. This hierarchical configuration and the assignment of geography- independent classes makes REC-Chile an easy way of interpreting the hydrological classes. Given the flexibility provided by the multi-scale nature of REC-Chile, and the simplicity in the interpretation of the classes, it is expected that REC-Chile will become a very useful and suitable tool for developing conservation plans for aquatic ecosystems.
\end{abstract}

KEYwORDS: Hierarchical classification, controlling factors, hydrological pattern, rivers, Chile.

\section{RESUMEN}

En Chile existe un aumento en la preocupación por proteger y conservar los ecosistemas acuáticos debido al elevado estado de deterioro del hábitat. Como un primer paso para desarrollar planes de conservación, se hace necesario realizar una clasificación de estos ecosistemas para conocer y entender los distintos tipos y su funcionamiento. Entendiendo que el caudal es el principal factor en la composición de ecosistemas fluviales, se ha desarrollado una clasificación EcoHidrológica de los ríos de Chile (REC-Chile) basada en una superposición jerárquica de factores controladores del patrón hidrológico en Chile. REC-Chile es multiescalar, permitiendo según los factores controladores seleccionados representar distintos patrones fluviales a diversas escalas espaciales. La tipología del tramo de río se representa como un código de 6 dígitos, en donde la posición del dígito representa el factor controlador y el valor a la categoría de éste. Esta configuración jerárquica, así como la asignación geográficamente independiente de sus clases, dota a la REC-Chile de facilidad en la interpretación hidrológica de las clases. Debido a la ductilidad y flexibilidad, entregada por la multiescalaridad y por la sencilla interpretación de sus clases, se espera que la REC-Chile se convierta en una herramienta para desarrollar planes de conservación de los ecosistemas acuáticos.

Palabras clave: Clasificación jerárquica, factores controladores, patrón hidrológico, ríos, Chile.

\section{INTRODUCTION}

Concern over the sustainable management of continental waters bodies is constantly increasing worldwide, in both the public and private ambit. Chile is also involved in this process, since the river ecosystems distributed over the whole length of the country have extraordinary value due to the high degree of endemicism of the species they contain, 
among others. About aquatic vertebrates, the endemicism reported to date is $81 \%$ for fish (Habit et al. 2006) and $60.7 \%$ for amphibians (Ortiz \& Díaz-Páez 2006). Among aquatic invertebrates an endemicism of $91.7 \%$ has been reported for gastropods (Valdovinos 2006), 30.8\% for bivalves (Parada \& Peredo 2006), 74.4\% for malacostracans (Jara et al. 2006), 56\% for Ephemeropteres (Camousseight 2006) and 57\% for Plecopteres (Vera \& Camousseight 2006). Furthermore, given the increasing deterioration and/or fragmentation of habitats, freshwater species today present serious conservation problems (Habit et al. 2006, Ortíz \& Díaz-Páez 2006, Parada \& Peredo 2006, Valdovinos 2006, Perez-Losada et al. 2002, Bahamonde et al. 1998).

To date, few information exists about conservation measurements for Chilean freshwater species (Peredo et al. 2006, Parada \& Peredo 2005, Peredo et al. 2005, Habit et al. 2002) and their habitats (Habit et al. 2006). Likewise, most of these studies lack of accuracy on local distribution (Habit et al. 2006, Parada \& Peredo 2006, Valdovinos 2006), which one is indispensable information for carrying out management and conservation programmes of Chilean freshwater species and river ecosystems.

The Chilean Government has developed the National Strategy for Hydrographic Basins (Estrategia Nacional de Gestión Integrada de Cuencas Hidrográficas - ENGICH) as an instrument for the protection and conservation of aquatic ecosystems; its role is to contribute to the sustainable use of water resources, harmonizing the protection of ecosystems with the availability of the resource (CONAMA 2007). To ensure the appropriate implementation of ENGICH, all the water bodies existing in the country must be studied and classified.

Landscape classifications have been developed for management purposes, as tools for understanding ecosystems. Such classifications allow data interpretation, inventories development, the extrapolation of information from specific sites to larger areas, development of objects and standards, etc. (Bailey 2009; Omernik \& Bailey 1997).

There are a variety of methods for developing a classification of natural aquatic systems, including taxonomic classification and those based on regionalization. Taxonomic classifications are not necessarily based on the physical or ecological processes which govern aquatic ecosystems. Methods based on regionalization, also known as ecoregions, respond to a physical focus which considers the control variables of fluvial processes and their patterns (González del Tánago \& García de Jalón 2006; Bailey et al. 1978). The ecoregions are homogeneous zones with regard to certain characteristics or parameters on a determined spatial scale (Snelder et al. 2005; Omernik \& Bailey 1997; Bailey et al. 1978). Snelder and Biggs (2002) pointed out that these ecoregions are unable to represent the longitudinal gradients in a river ecosystem, which were synthesized in the River Continuum Concept (Vannote et al. 1980); therefore the use of such ecoregions for river classification are limited.

Since the 1980's several authors have addressed landscape classification by means of hierarchical organization systems for rivers. They recognise that rivers belong to a basin, which one feeds them. Therefore, it is expected that the rivers are being influenced by the watershed characteristics, accepting that ecological processes in a river depend on physical factors which occur at several scales (González del Tánago \& García de Jalón 2006, Snelder \& Biggs 2002, Montgomery \& Buffington 1997, Omernik \& Bailey 1997, Frissell et al. 1986).

Snelder and Biggs (2002) developed the River Environmental Classification (REC) to classify the rivers of New Zealand based on the following premises: a) Ecological patterns are dependent on a number of factors associated with the regional scale of the various physical processes; b) The ecological characteristics of rivers respond to fluvial processes; and c) Classes are assigned to each segment of river geographically independent. In the REC, the typology of each river segment is determined by the hierarchical superposition of controlling factors, which are the principal causes of the spatial variation of the hydrological pattern at a determined scale (Snelder $e t$ al. 2005, Snelder \& Biggs 2002).

There are many eco-hydrological similarities between the rivers of Chile and those of New Zealand. Hydrological regime, river geomorphology, and presence of certain fish taxa, e.g. Galaxias maculatus and Geotria australis (Vila et al. 2006, Dyer 2000, Mc Dowall 2000) and numerous species of macroinvertebrates (Winterbourn 1981) are among the main similarities that we found. Due to this, we hypothesized that these similarities would enable the REC to be adapted for Chile, taking into account the existing geomorphological and climatic differences, expecting that it would constitute a management tool for Chilean river ecosystems.

The present work has two objectives: to implement a REC in Chile (REC-Chile), and to interpret some of its classes for its application in management and planning of river ecosystems.

\section{METHODS}

REC-CHILE CONTROLLING FACTORS

The controlling factors selected for the implementation of REC-Chile are based on those used in the REC developed 
by Snelder and Biggs (2002) for New Zealand, adapted to the climatic and environmental conditions of Chile. The controlling factors selected were: Climate, Source of Flow, Geology, Catchment Relative Position, Land Use and Reach Slope. Each one of these are subdivided into a categories according to controlling factors meaning.

In the hierarchy of REC-Chile, Climate is the only macro-scale controlling factor. Principally, it determines hydrological characteristics such as flow magnitude and frequency of flooding and low flow period (Snelder et al. 2005; Snelder \& Biggs 2002). The categories used were based on Blair's climate classification Arid, Semi-Arid, Mid-Wet, Wet and Very Wet (Heras 1973).

The Source of Flow factor acts at a mesoscale level, indicating the stream flow is originated by rainfall, snowmelt, glaciers or a combination of these (Fleming 2005, Snelder et al. 2004). This controlling factor has its origin from the topography of the watershed (Snelder et al. 2002) considering how this impacts on flow regime. Thus, this controlling factor is related to seasonality of flow regimes, sediments supply and transport process at a watershed scale (Snelder \& Biggs 2002). Precipitation in Chile is mainly related to orographic effects, since the Andes mountain range acts as a barrier to the moist winds coming from the Pacific Ocean (Villagrán \& Hinojosa 2005; Rutllant 2004). This fact makes possible associate the altitude of a watershed with its precipitation as proportion to the total precipitation of the whole basin.

The Source of Flow factor includes five categories of topographical origin (Low Elevation, Valley, Mid-Mountain, Mountain and Eternal Snow) and three categories which ones due to their physical characteristics change the flow regime (Lakes, Glaciers and Regulations). The categories of topographical origin were assigned by a relationship between catchment mean altitude and its accumulated precipitation percentage with respect to the total rainfall basin. Thus, the Low Elevation category refers to watershed at 300 masl or lower. This category present a low accumulated precipitation, less than $25 \%$ of the total rainfall basin, and extreme seasonal variations between summer and winter. Valley corresponds to a watershed located between 300 and 1000 masl, with percentages of accumulated precipitation averaging between $25 \%$ and $40 \%$ of the total rainfall basin. This category present a higher mean annual flow and more moderate seasonal variations than Low Elevation. Midmountain refers to watersheds between 1000 and 2400 masl, with high percentages of accumulated precipitation (between 40 and $70 \%$ ) incorporating, the contribution of snow-melt during spring-summer; this leads to the formation of a higher peak flow in winter (high rainfall period) and another smaller peak in spring-summer (dry period). Mountain corresponds to watershed between 2400 and 4200 masl, characterised by a high contribution of snow-melt and small amounts from precipitation, resulting in a small peak in the flow regime in winter and another larger peak in early summer. Eternal snow are watersheds above 4200 masl They only receive snow-melt, presenting high flows in summer and low in winter.

Among flow modifier categories, the Glacier category is assigned to any reach river whose watershed contains a glacier with an area covering more than $20 \%$. Lakes refer to water bodies where flow regime is modified by significant water storage, usually reducing and delaying flood events. To evaluate whether such a modification is produced, the Lake Index (LI) is calculated (Equation 1) which estimates the precipitation on the lake as compared to the basin which drains into the river reach.

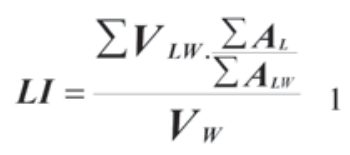

Where: $A_{L}$ is the lake area, $A_{L W}$ is the lake watershed area, $\mathrm{V}_{\mathrm{LW}}$ is the mean annual precipitation in the lake watershed, and $\mathrm{V}_{\mathrm{w}}$ is the annual precipitation of the basin.

The LI index evaluates whether or not the influence of water body represents a significant modification to the hydrograph of a watershed; it was proposed by Snelder and Biggs (2002) and modified later (T. Snelder pers. comm.). To determine the threshold value for the LI in Chilean rivers a comparison between annual hydrographs of gauging stations with the same REC-Chile code, with and without the presence of a lake upstream was made. The critical value for this was estimated at 0.020 , meaning significant regulation effect by the lake at values above this threshold.

Given that categories of Source of Flow factor are related to hydrological patterns in a natural regime, it was necessary to incorporate the category Regulations to take into account man-made regulation structures.

The Geology factor is related, at mesoscale level, to the water geo-chemical characteristics, dominated by the geological properties of the aquifer (Herrera et al. 2006; Gonzalez et al. 1999). An important parameter of water quality in Chilean rivers is constituted by dissolved salts due to the marine and/or volcanic origin of the basins (Vila \& Molina 2006), showing a pronounced north-south gradient. This factor defined eight categories as follow: Alluvial, Plutonic Rocks, Volcanic Rocks, Sediment and Mix of Sediment and Volcanic Rocks (Sedim and Mix Sed-Volc Rocks), Sedimentary Rocks, Fractured Volcanic Rocks and Carbonated Rocks. A category named Not Recognised was 
incorporated for cases where it is impossible to establish the geological origin.

Catchment Relative Position is the fourth controlling factor. It is related to the catchment area of a river reach as a proportion of the whole basin. It describes aspects of the hydrological pattern such as magnitude of mean flow, intensity and attenuation of flood flows, and flux of sediments. The assignation rule was determined according to the relative position of the catchment within the basin, defining the following categories: Headwater, Upper Reach, Middle Reach and Low Reach. The categories Endorreic and International (i.e. transboundary river) were assigned manually.

The Land Use factor is related to mesoscale processes, such as initial interception and evapotranspiration; it also controls physical-chemical aspects of the water quality resulting from soil leaching into, or carried down by, the river (Sliva \& Dudley 2001; Johnson et al. 1997). Nine categories were defined: City Areas, Agriculture, Praire and Shrubs, Woods, Areas without Vegetation, Reservoirs, Snow and Glaciers and Areas without Information.

The last controlling factor is Reach Slope. This describes morpho-hydraulic patterns at a microscale level such as local transport of sediment, river-bed erosion, mean velocity of flow and influence of bank conditions. The assignation rule is determined according to the slope along the river reach in three categories: Low, Medium and High.

\section{REC-ChiLE IMPLEMENTATION}

REC-Chile was implemented through Geographical Information System (GIS) in rivers represented as a digital hydrographic network at 1:250,000 scale. The information used to develop the classification, as well as the river network, was provided by the Bureau Water Management of Chile (Dirección General de Aguas - DGA). This information includes precipitation contours, potential and actual evapotranspiration contours $(1: 250,000)$, elevation contours $(1: 250,000)$, watershed areas $(1: 50,000)$, basin areas $(1: 50,000)$, geology $(1: 50,000)$ and land use $(1: 50,000)$.

The REC-Chile mapping was done according to the spatial scale of each controlling factor (top-down scaling) following the assignation rules defined for each category. In Climate, Source of Flow and Geology categories factors, the concept of River Continuum was considered (Vannote et al. 1980) propagating downstream the characteristics of the most influential categories. In Climate factor, four categories were propagated which ones dominate the flow magnitude. The order of propagation of these categories was: Semi-Arid, Mid-Wet, Wet and Very Wet. In Source of Flow factor, seasonal characteristics of the hydrograph were propagated. First one, the topographical categories were propagated (Low elevation, Valley, Mid-Mountain, Mountain and Eternal Snow) and, second one, the categories assigned manually (Lakes, Glaciers and Regulations). In Geology factor, propagation criterion was based on the dissolved salts contribution due to the lithology of different soil types. The propagation order of these categories was: Plutonic Rocks, Volcanic Rocks, Sedimentary and Mix SedVolcanics Rocks, Sedimentary Rocks, Fractured Volcanic Rocks, and finally Carbonated Rocks.

REC-Chile was developed in basins located between 18 and $43^{\circ} \mathrm{S}$. The classification was not implemented in the more southerly basins $\left(43^{\circ} \mathrm{S}\right.$ to $\left.55^{\circ} \mathrm{S}\right)$ due to lack of information to define the controlling factors.

Once REC-Chile had been designed and implemented, two simple applications were done to show how to interpret the REC-Chile classes to determine the hydrological pattern and the natural geo-chemical quality of the waters. In a first case, basic aspects of mean annual hydrograph from 4 gauging stations in natural or slightly modified regimes were compared with their respective REC-Chile codes, which ones were obtained by the Climate and Source of flow hierarchical superposition (second level). In the second case, the mean electrical conductivity (EC) in 67 segments of river distributed throughout Chile were compared with their respective REC-Chile codes at a third level, which ones were obtained by the Climate, Source of Flow and Geology hierarchical superposition. The data for the annual hydrographs and the EC were provided by DGA.

\section{RESULTS}

\section{REC-CHILE CLASSIFICATION}

Table 1 shows the REC-Chile with each one of the controlling factors and its categories, assignment rules and the code associated to each category.

The resulting classification presents a tree structure in which each category of controlling factor number $i$ are divided among the categories of controlling factor $i+1$. The classification levels are defined according to the hierarchical superposition controlling factors.

The first classification level corresponds to the first controlling factor (Climate), the second classification level is the hierarchical superposition of the first two factors (Climate and Source of Flow), the third level is defined by adding the Geology factor to the second level and so on down to the sixth and last classification level defined by the hierarchical superposition of all the REC-Chile controlling factors. The sixth classification level is reflected in a six- 
digit code. The digit position represents the classification level and the digit value represents the category of the controlling factor at this level.

The classes are defined according to the hierarchical superposition of the factor categories at the level selected. Thus for the first level the classes are the Climate categories, for the second level the resulting classes are the Climate categories combined with the Source of flow categories, i.e. Arid is combined with the categories Low Elevation, Valley, Mid-Mountain, Mountain, Eternal Snow, Lakes, Regulations and Glacier. This procedure is repeated for each controlling factor categories until the Reach Slope factor to create all classes at sixth level of classification.

The potential number of classes in any classification level depends on the number of categories at that level and the number of classes in the previous levels, and thus the potential number of classes is given by the mathematical combination of the number of categories in each controlling factor. For example, the second level potentially has 40 classes $(5 \times 8)$, the third level potentially has 320 classes $(5$ x 8 x 8). REC-Chile has 46,080 potential classes. However, not all the potential classes occur physically in the RECChile domain, in which exists 3049 classes in a total area of $515,000 \mathrm{~km}^{2}$ aproximatelly.

Due to the spatial scale of each controlling factor, the classes at Climate level define larger homogenous areas than the classes at the Source of flow level, and this generates differences in the spatial scale of the patterns generated. Figure 1 shows the classification at the first two levels for two basins located in northern Patagonia (Imperial and Toltén Rivers). This shows the downstream propagation of the most influential categories. At the first level (Fig. 1b), propagation of Very Wet $(\mathrm{Vw})$ category coming from the rains which occur in the Andes mountains can be observed. Likewise, the second level (Fig. 1c) shows the propagation of the Very Wet / Mid-Mountain class $(\mathrm{Vw} / \mathrm{Mm})$ in the Imperial River and the Very Wet / Lakes class $(\mathrm{Vw} / \mathrm{La})$ in the Toltén River. On the one hand, this would mean that the hydrograph of the Imperial River should have a seasonal pattern approximately similar to the Andes mountains precipitation regime; on the other hand, the hydrograph of the Toltén River would be influenced by the damping effect of the Villarrica Lake.

TABLE 1. REC-Chile classification levels, factors, categories, codes and assignment rules.

TABla 1. Niveles de clasificación de la REC-Chile, sus categorías, códigos y reglas de asignación.

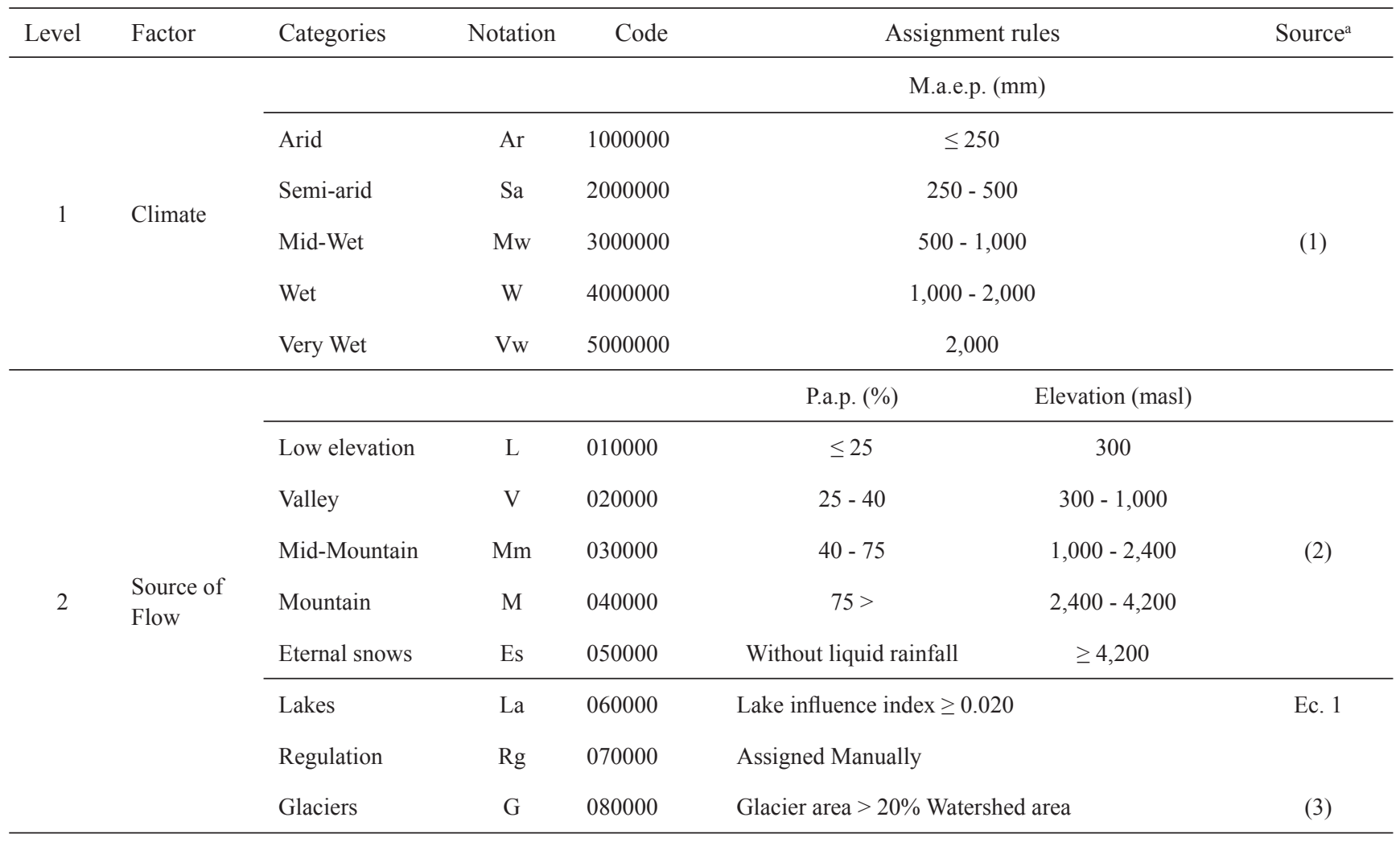


Continuación Table 1.

\begin{tabular}{|c|c|c|c|c|c|c|}
\hline Level & Factor & Categories & Notation & Code & Assignment rules & Source $^{\mathrm{a}}$ \\
\hline \multirow{8}{*}{3} & \multirow{8}{*}{ Geology } & $\begin{array}{l}\text { Deposit non } \\
\text { consolided }\end{array}$ & $\mathrm{Al}$ & 001000 & & \multirow{8}{*}{ (4) } \\
\hline & & $\begin{array}{l}\text { Plutonic and } \\
\text { hipabisal }\end{array}$ & $\mathrm{Pl}$ & 002000 & & \\
\hline & & Volcanic & $\mathrm{Vc}$ & 003000 & & \\
\hline & & $\begin{array}{l}\text { Sed. and mix } \\
\text { sed-volc }\end{array}$ & Mx & 004000 & & \\
\hline & & $\begin{array}{l}\text { Metam. and } \\
\text { sedimentary }\end{array}$ & Ms & 005000 & & \\
\hline & & $\begin{array}{l}\text { Fractured } \\
\text { Volcanic }\end{array}$ & Vf & 006000 & & \\
\hline & & Carbonate & $\mathrm{Ca}$ & 007000 & & \\
\hline & & $\begin{array}{l}\text { Area without } \\
\text { information }\end{array}$ & $\mathrm{Ni}$ & 008000 & & \\
\hline \multirow{7}{*}{4} & \multirow{7}{*}{$\begin{array}{l}\text { Catchment } \\
\text { Relative } \\
\text { position }\end{array}$} & & & & $\begin{array}{c}\text { Accumulated catchment } \\
(\% \text { basin area })\end{array}$ & \\
\hline & & Headwater & $\mathrm{Hw}$ & 000100 & $\leq 7.5$ & \multirow{4}{*}{ (2) } \\
\hline & & Upper reach & Ur & 000200 & $7.5-25$ & \\
\hline & & Middle reach & $\mathrm{Mr}$ & 000300 & $25-70$ & \\
\hline & & Low reach & $\mathrm{Lr}$ & 000400 & $\geq 70$ & \\
\hline & & Endorreic & $\mathrm{E}$ & 000500 & Basin without flow outlet to the sea & $(5)$ \\
\hline & & International & I & 000600 & International basin & (5) \\
\hline \multirow{9}{*}{5} & \multirow{9}{*}{ Land Use } & City & $\mathrm{Ci}$ & 000010 & & \multirow{9}{*}{ (6) } \\
\hline & & Agriculture & $\mathrm{Ag}$ & 000020 & & \\
\hline & & $\begin{array}{l}\text { Prairie and } \\
\text { shrubs }\end{array}$ & Ps & 000030 & & \\
\hline & & Woods & Wo & 000040 & & \\
\hline & & $\begin{array}{l}\text { Area without } \\
\text { vegetation }\end{array}$ & $\mathrm{Nv}$ & 000050 & & \\
\hline & & Reservoir & $\mathrm{R}$ & 000060 & & \\
\hline & & Wetlands & $\mathrm{Wt}$ & 000070 & & \\
\hline & & $\begin{array}{l}\text { Snow and } \\
\text { glaciers }\end{array}$ & $\mathrm{Sg}$ & 000080 & & \\
\hline & & $\begin{array}{l}\text { Area without } \\
\text { information }\end{array}$ & $\mathrm{Ni}$ & 000090 & & \\
\hline \multirow{4}{*}{6} & \multirow{4}{*}{ Slope } & & & & Slope (\%) & \\
\hline & & High & $\mathrm{Hi}$ & 000001 & $>0.04$ & \multirow{3}{*}{ (3) } \\
\hline & & Medium & $\mathrm{Md}$ & 000002 & $0.04-0.02$ & \\
\hline & & Low & $\mathrm{Lw}$ & 000003 & $\leq 0.02$ & \\
\hline \multicolumn{7}{|c|}{$\begin{array}{l}{ }^{*} \text { M.a.e.p = Mean annual effective precipitation. } \\
\text { **.a.p = Percentage of accumulate precipitation } \\
\text { a: (1) Climatic classification of Blair; (2) Own construction; (3) Snelder et al. (2005); (4) lithology (DGA); (5) Hydrological network } \\
\text { (DGA); (6) Land use (DGA). }\end{array}$} \\
\hline
\end{tabular}




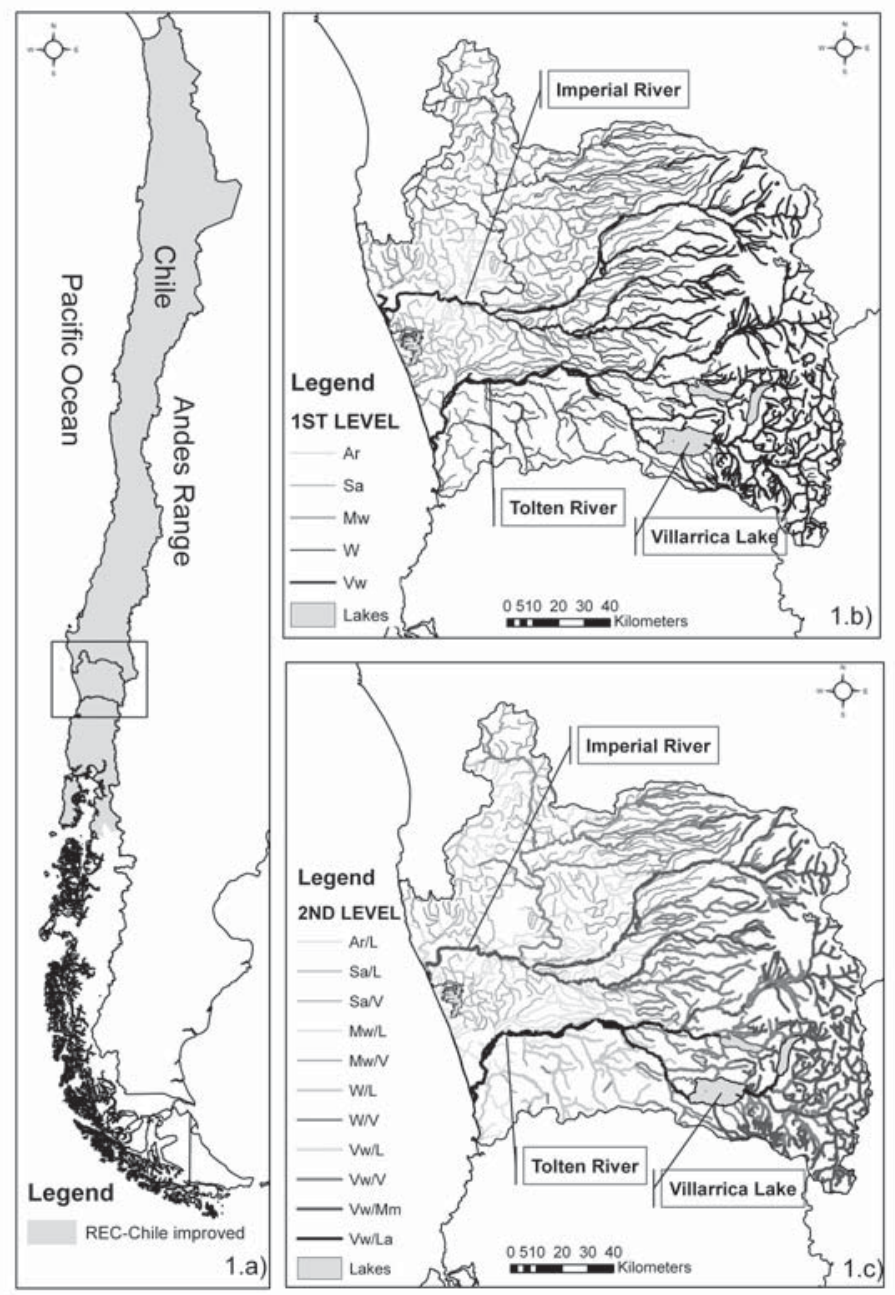

FIGURE 1. Geographic range where REC-Chile was implemented (1.a). The upper figure (1.b) shows the first REC-Chile level (Climate) in the Imperial and Toltén River basins. The lower figure (1.c) shows the second REC-Chile level (Climate and Source of Flow) in the same basins. For more detail on REC-Chile class interpretation see Table 1.

Figura 1. Rango geográfico en el cual la clasificación REC-Chile fue implementada (1.a). La figura superior (1.b) muestra el primer nivel de la REC-Chile (Climate) en las cuencas del río Imperial y Toltén. La figura inferior (1.c) muestra el segundo nivel de clasificación de la REC-Chile (Climate y Source of Flow) en las mismas cuencas mencionadas anteriormente. Para más detalle sobre la interpretación de las clases de la REC-Chile ver Tabla 1.

\section{REC-CHILE CLASSES INTERPRETATIONS}

By combining certain controlling factors it is possible to interpret some eco-hydrological patterns of river system. The second classification level allows to determine the magnitude of the mean annual flow of a river reach in its natural regime, as well as its seasonal variation. Classes at this level are able to provide a descriptive interpretation of a mean annual hydrograph of river reaches in a natural regime. Classes with categories Arid and Semi-arid are expected to present a low mean annual flow. Within these categories, those where rainfall is the main source of flow (Low Elevation and Valley) tend to show an intermittent or ephemeral flow regime, with large seasonal variations between the summer (minimum flows) and winter (high flows). Reaches in the Mid-mountain category are expected to present intermittent flows with bimodal hydrographs, as a result of the combined contribution of precipitation and snow-melt. Mountain and Eternal Snow categories will have moderate seasonal variation from the mean annual flow, with the maximum flows occurring when snow is melting and a minimal base flow during the rest of the year. Likewise Glacier category is expected to present flow according to the melt-rate of the glaciers. Lakes category will not be found in combination with Arid and Semi-arid categories.

Reaches in the Mid-Wet category tend to have higher mean annual flow than the ones in the two previous categories. The categories related to rainfall usually indicate permanent 
flow with seasonal variations corresponding to rainfall regime. Mid-mountain category is related to bimodal annual hydrographs, but with a higher peak flow in winter than in Arid and Semi-arid categories. Mountain, Eternal Snow and Glacier categories present high flows in late spring and early summer. The combination Mid-Wet and Lakes categories do not exist.

For Wet and Very Wet categories, higher mean annual flows can be expected. The presence of rainfall categories is related to continuous flows and an important increase at peak flow periods. Mid-Mountain and Mountain categories will present bimodal hydrographs; in the case of MidMountain, the higher peak flow will occur in winter due to rainfall, whereas the opposite will be possible of the Mountain category due to the contribution of snow-melt in summer. Eternal Snow and Glacier categories will have a similar behaviour to Mountain category. Lakes category means a damping effect of the seasonal flow variations, and alteration flow timing; extreme flows are expected to occur in late winter and late summer. The classes combining Very Wet and Eternal Snow categories do not exist.

Table 2 shows the REC-Chile codes, at the second level of classification, for four gauging stations distributed along the country. Based on these codes a descriptive interpretation is made of the mean annual hydrograph.

The Salado River station belongs to Arid and Eternal Snow class (Ar/Es). For this class the hydrological pattern may be expected to present low mean annual flows, with maximum mean monthly flows at snow-melt season (January to March) and minimum mean monthly flows in the cold season (June to August). The Choapa River station belongs to Mid-wet and Mountain class (Mw/M). This station may be expected to have higher mean annual flows than the Salado River station. The hydrograph should present two peaks, one at the start of the snow-melt season
(November and December) and another smaller peak in the rainy season (June to August). The Aconcagua station is inside Wet and Glacier class (W/G), where the mean annual flow should be greater than previous station. The hydrograph should have a maximum mean monthly flow at early summer (December and January) and relatively low flow during the rest of the year. Finally, the Itata station belongs to Very Wet and Mid-mountain class (Vw/Mm), where the mean annual flow should therefore be higher than all others stations. The maximum monthly mean flows should be during the rainy season (June to August) and the minimum mean monthly flows in the summer months (January to March).

The mean annual flows of each gauging station (Table 2) and their mean annual hydrographs (Fig. 2) are in agreement with the classification. For all the stations, the shape of the hydrograph is similar to that described by the REC-Chile classes, just as are the seasonal variations too.

To characterize the natural geo-chemical quality of the water, the following aspects must be considered: local lithology, climate, vegetation and residence time of the water in the aquifer, which is a function of the climate (Drever 2002). Another important aspect to be considered is the composition of the inflow water on the system (Allan \& Castillo 2007) and the origin of the water circulating in the river. The controlling factors used to characterize the natural geo-chemical quality of the water are Climate, Source of Flow and Geology. Therefore, the third level of classification enables to make a prediction of the mean Electrical Conductivity (EC, $\mu \mathrm{S} / \mathrm{cm}$ ) for each class.

Arid category of the Climate factor is expected to have a high EC value, and as the level of precipitation rises, the EC will diminish; thus Very Wet category should have the lowest EC. The categories of the second controlling factor, Source of Flow, have less effect on the EC than Climate

TABLE 2. Gauging stations and respective REC-Chile code of segments used to interpret the hydrological pattern.

TABLA 2. Estaciones fluviométricas y sus correspodientes códigos REC-Chile de los tramos de ríos que fueron utilizados para interpretar el patrón hidrológico.

\begin{tabular}{lcccc}
\hline Gauging stations & River Basin & Q50 (m $\left.{ }^{3} / \mathbf{s}\right)$ & REC-Chile code & $\begin{array}{c}\text { Notation at second } \\
\text { level }\end{array}$ \\
\hline Salado River before confluence with Curti River. & Loa & 0.094 & 154133 & Ar/Es \\
Choapa River in Salamanca. & Choapa & 4.930 & 345223 & $\mathrm{Mw} / \mathrm{M}$ \\
Aconcagua River in Chacabuquito. & Aconcagua & 28.038 & 485321 & $\mathrm{~W} / \mathrm{G}$ \\
Itata River in Coelemu. & Itata & 310.405 & 535453 & $\mathrm{Vw} / \mathrm{Mm}$ \\
\hline
\end{tabular}




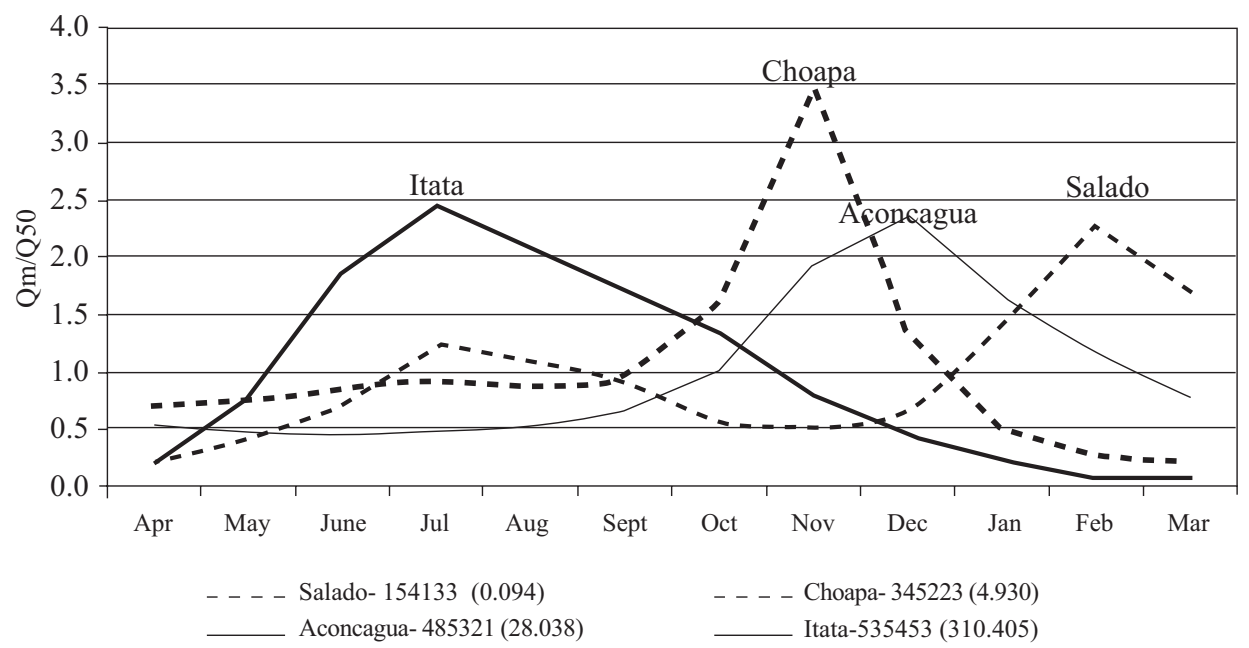

FIGURE 2. Mean annual hydrograph of four gauging stations associated with 4 REC-Chile codes. The mean annual volume flow for each station is shown in parentheses. For the interpretation of the REC-Chile code see Table 1 . The Y axis (Qm/Q50) represents the ratio between mean monthly discharge and annual discharge with a 50\% of excedence probability. For the association of the REC-Chile code with the corresponding gauging station see Table 2.

FIgURA 2. Hidrograma medio anual de cuatro estaciones fluviométricas asociadas a sus respectivos códigos de la REC-Chile. El caudal medio anual por cada estación es mostrado entre paréntesis. Para interpretación de los códigos de la REC-Chile ver Tabla 1. El eje Y (Qm/Q50) corresponde a la razón entre el caudal medio mensual y el caudal anual con una probabilidad de 50\% de excedencia. Para ver la asociación de cada código con su correspondiente estación fluviométrica ver Tabla 2.

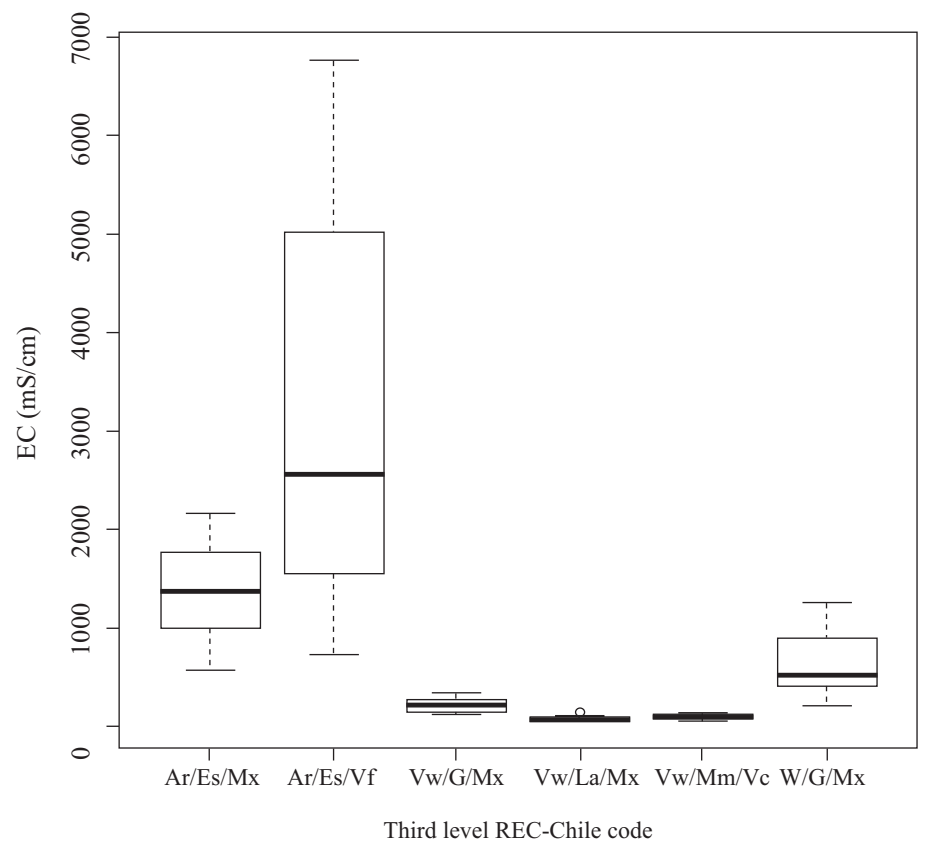

Figure 3. Mean, 25 and $75 \%$ percentiles, and maximum and minimum values for Electrical Conductivity ( $\mu$ S/cm) of the 6 REC-Chile classes. The numbers on the X axis indicate the code of the REC-Chile classes at the third hierarchical level, with the first digit representing the Climate factor category, the second digit representing the Source of Flow factor categories and the third digit representing the Geology factor (see Table 1).

FIGURA 3. Valores medios, percentiles $25 \%$ y $75 \%$ y valores máximos y mínimos de Conductividad Eléctrica $(\mu \mathrm{S} / \mathrm{cm})$ para 6 clases de la REC-Chile. El eje X indica el código de las clases de la REC-Chile a un tercer nivel de clasificación. El primer dígito corresponde a las categorías del factor Climate, el segundo dígito representa al factor Source of Flow y el tercer dígito al factor Geology (ver Tabla 1). 
factor. Categories with a rainfall origin (Low Elevation, Valley and Mid-Mountain) present a lower EC than those coming from snow-melt (Mountain, Eternal Snow and Glacier) due to leaching from volcanic soils. Lakes category may present lower values due to the physical-chemical processes which occur in lakes. Finally, the third factor categories (Geology) presents EC values according to the presence of ions associated with each type of lithology. Thus Alluvial category will present the lowest EC values, followed by Plutonic Rocks, Volcanic, Sediment and Mix Sed-volcanic, and finally Sedimentary Rocks. A special case is the category of Fractured Volcanic Rocks, since this permits to occur a greater leaching of ions.

Figure 3 shows the EC values of sampling points grouped by the third level REC-Chile code. These values appear to be in agreement with the interpretations done from the REC-Chile classes. It is observed that the classes with Arid category (Ar/Es/Mx and $\mathrm{Ar} / \mathrm{Es} / \mathrm{Vf}$ ) present the highest values and that these diminish as the level of precipitation increases. The effect of Source of Flow factor is also observed, since within the Very Wet category, the Glaciers category $(\mathrm{Vw} / \mathrm{G} / \mathrm{Mx})$ presents the highest concentration, while Lakes category $(\mathrm{Vw} / \mathrm{La} / \mathrm{Mx})$ has a lower EC concentration. Finally in the class Ar/Es, it is seen that the Fractured Volcanic Rocks category has a higher concentration than compound rocks of volcanic and sedimentary origin.

\section{DISCUSSION}

The results of this study show that it is possible to implement the REC in the particular environmental conditions existing in Chile. The controlling factors and categories developed for this country seem to represent in a suitable way the various climatic, hydrological and geological conditions. For example, using REC-Chile at the second level, i.e. combining the Climate and Source of Flow factors, it is possible to describe approximately the hydrological pattern of a segment of river. This allows compare magnitudes of mean annual flow between segment of river for different classes and estimate a first approach of the annual hydrograph, as is shown in the present study.

Furthermore, at the third classification level a good characterization of the geo-chemical quality of the water could be achieved. It is in agreement with previous studies in which it is indicated that precipitation, the lithology of the basin, the origin of flow and the residence time are the principal factors (Allan \& Castillo 2007; Drever 2002; Custodio \& Llamas 1976).

It must be stressed that REC-Chile incorporates the River
Continuum Concept (Vannote et al. 1980) and represents the longitudinal changes downstream as a result of the propagation of upstream characteristics in the downstream directions.

The development of REC-Chile in a GIS environment allows the observation and easy handling of the river segment's data. One great advantage of this tool is the possibility of managing information coming from the controlling factors selected by the user according to the objectives and the scale of the work. This give it great flexibility to obtain patterns of the distribution of hydrological and physical-chemical variables which determine the ecological characteristics of segments of river.

REC-Chile classification is able to classify rivers at a microscale equivalent to river reach ( $\mathrm{km}$ order). This prevents the REC-Chile to classify rivers considering fluvial processes that ocurr at a lower spatial scale. If required to carry out a classification at a lower spatial scale than river reach, it would be necessary to decrease the classification unit (for example at mesohabitat unit). Any modification to REC-Chile, either including controlling factors and/or categories will result in an increase of the total number of classes.

A joint use of the REC-Chile and a geodatabase of aquatic communities, e.g. macroinvertebrates or fish, brings great benefits in terms of its use in management and planning of aquatic ecosystems (Peredo-Parada et al. 2009a). Among other things, REC-Chile will enable estimating spatial distribution patterns for species with scarce information, because statistical techniques can relate the physical characteristics of the river segments with species presence/ absence data (Peredo-Parada et al. 2009b; Snelder et al. 2004). It is also helpful in the design of monitoring networks, in order to ensure a suitable distribution of sampling points across an area of interest (Hawkins et al. 2000), and also to investigate about habitat suitability for aquatic species at the mesoscale level.

In order that a landscape classification becomes a useful aquatic management tool, it must be developed by consensus of all sectors involved in management of aquatic ecosystems. Furthermore, the landscape classification must have a number of classes that facilitates handling and decision making. The great number of REC-Chile classes goes against this premise, could result in a complex management framework. Therefore, it is necessary to decrease the number of classes. This reduction must be carried out by evaluating the classification strength at different number of classes and will be necessary to perform a physical interpretation of the classes. These two analysis will allow to group the classes that present a similar interpretation without missing the correct classification structure. Due to the tree configuration 
of the REC-Chile to achieve a great reduction in the total number of classes, the number of categories at higher level must be decreased,

Other important application of the REC-Chile is the determination of river reaches in natural condition, which could be used as a reference in restoration planning (Hawkins et al. 2000). If there are no reaches in natural conditions, REC-Chile allows to assess the maximum ecological potential within a certain class using various indexes, e.g. freshwater fish index (Noble et al. 2007; Schmutz et al. 2007), macroinvertebrates index (Figueroa et al. 2003, 2007), and riparian vegetation index (Palma \& Figueroa 2009; Munné et al. 1998, 2003). With the application of such kind of indexes, REC-Chile could make possible to determine the hydrologic and ecological degree of alteration of river segments, in relation to reference sites. It can also be used to extrapolate ecological information within the classes (Omernik \& Bailey 1997). These applications are useful for prioritizing and designing fluvial restoration activities.

\section{CONCLUSIONS}

The REC-Chile classification system is an adaptation to the climatic, topographic and geological conditions of Chile of the River Environmental Classification (REC) developed by Snelder \& Biggs (2002).

This classification system is a tool for river classification with a digit-code based on the hierarchical superposition of six factors which control the hydrological pattern (Climate, Source of Flow, Geology, Catchment Relative Position, Land Use and Reach Slope). The classification of river reaches is represented as a 6-digit code, where the digit position is the classification level and its value is the category of the factor at that level.

REC-Chile offers various advantages with respect an ecorregion approach. First, it allows the various ecohydrological patterns of Chilean rivers to be described by the superposition of appropriate controlling factors depending on the objective of the classification, thus allowing study on various spatial scales. Second, it has the ability to manage rivers as hydrological networks considering their longitudinal continuity, allowing changes to be detected from one watershed to another even if they are geographically close to one another, thus providing a more exact characterization of Chilean rivers. Third, it is implemented in a GIS environment, facilitating geographical interpretation and changes from one scale of work to another.

An easy interpretation of the REC-Chile classes at different classification levels enables a simple assessment of different fluvial patterns, e.g. at the second classification level the mean annual hydrograph of river segments can be described. At the third classification level, aspects of the natural geochemical quality of the water can be compared.

Finally we expect the REC-Chile classification system become a useful tool for the conservation and management of river ecosystems in Chile, supporting the determination of their ecological potential state and the selection of suitable methods for assigning environmental flow regimes in different river types.

\section{ACKNOWLEDGMENTS}

This research has been supported by National Committee of Sciences and Technology (CONICYT) and Spanish Agency of International Cooperation for Development (AECID) through grant for Matias Peredo. We wish to thank to General Water Authority of Chile (DGA) for providing the data sets.

\section{REFERENCES}

Allan, D. \& Castillo, M. 2007. Stream ecology. Structure and function of running waters. $2^{\text {nd }}$ edition. Springer Dordrecht, The Netherlands. $436 \mathrm{pp}$.

Baeza, D., Martínez-CApel, F. \& García de Jalón, D. 2003. Variabilidad temporal de caudales: Aplicación a la gestión de ríos regulados. Ingeniería del agua 10(4):469-478.

Bahamonde, N., Carvacho, A., Jara, C., López, M., Ponce, F., Retamal, M.A. \& Rudolff, E. 1998. Categorías de conservación de decápodos nativos en aguas continentales de Chile. Boletín del Museo Nacional de Historia Natural 47:91-100

Bailey, R.G. 2009. Ecosystem Geography. $2^{\text {nd }}$ Edition Springer. New York. EEUU. 251 pp.

Bailey, R.G., Pfister, R.D. \& Henderson, J.A. 1978. Nature of Land and Resource Classification. Journal of Forestry 76(10):650-655.

Camousseight, A. 2006. Estado de conocimiento de los Ephemeroptera de Chile. Gayana 70(1):50-56.

Conama 2007. Estrategia Nacional de Gestión Integrada de Cuencas Hidrográficas. Gobierno de Chile. 60 pp.

Custodio, E. \& Llamas, M. 1976. Hidrología Subterránea. Ediciones Omega S.A. Barcelona. 1157 pp.

Drever, J. 2002. The Geochemistry of Natural Waters. Surface and Groundwater Environments. Prentice Hall. Third Edition. New Jersey. ISBN: 0-13-272790-0. 436 pp.

DYER, B. 2000. Sistematic review and biogeography of the freshwater fishes of Chile. Estudios Oceanológicos 19:7798.

Figueroa, R., Valdovinos, C., Araya, E. \& Parra, O. 2003. Macroinvertebrados bentónicos como indicadores de calidad de agua de ríos del sur de Chile. Revista Chilena de Historia Natural 76:275-285. 
Figueroa, R., Palma, A., Ruiz, V. \& Niell, X. 2007. Análisis comparativo de índices bióticos utilizados en la evaluación de la calidad de las aguas en un río mediterráneo de Chile: Río Chillán, VIII Región. Revista Chilena de Historia Natural 80:225-242.

Fleming, S. 2005. Comparative analysis of glacial and nival streamflow regimes with implications for lotic habitat quantity and fish species richness. River Research and Applications 21:363-379.

Frissell, C., Liss, W.J., Warren, C.E. \& Hurley, M.D. 1986. A hierarchical framework for Stream Habitat Classification: Viewing Streams in Watershed context. Environmental Management 10:199-214.

González, L., Mardones, M., Silva, A. \& Campos, E. 1999. Hidrogeoquímica y comportamiento del agua subterránea en la cuenca del río Claro, Región del Biobío, Chile. Revista Geológica de Chile 26(2):145-157.

González del Tánago, M. \& García de Jalón, D. 2006. Propuesta de caracterización jerárquica de los ríos españoles para su clasificación según la Directiva Marco de la Unión Europea. Limnética 25(3):693-712.

Habit, E., GonzÁlez, S. \& Victoriano, P. 2002. Alcances sobre el uso sustentable de la ictiofauna de sistemas fluviales. Theoria 11:15-20.

Habit, E., Dyer, B. \& Vila, I. 2006. Estado de conocimiento de los peces dulceacuícolas de Chile. Gayana 70(11):100-112.

Hawkins, C., Norris, R., Gerritsen, J., Hughes, R., Jackson, S., Johnson, R. \& Stevenson, J. 2000. Evaluation of the use of landscape classifications for the predictios of freshwater biota: synthesis and recommendations. Journal of American Benthological Society. 19(3):541-556.

Heras, R. 1973. Estudio de sequias. Ediciones Centros de Estudios Hidrográficos, Madrid. $46 \mathrm{pp}$.

Herrera, C., Pueyo, J.J., Sáez, A. \& Valero-Garcés, B. 2006. Relación de aguas superficiales y subterráneas en el área del lago Chungará y lagunas de Cotacotani, norte de Chile: un estudio isotópico. Revista Geológica de Chile. 33(2):299-325.

Jara C.G., Rudolph, E.H. \& Riquelme, E.R. 2006. Estado de conocimiento de los malacostracos dulceacuícolas de Chile. Gayana 70(1):40-49.

Johnson L., Richards, C., Host, G. \& Arthur, J. 1997. Landscape influences on water chemistry in Midwestern stream ecosystems. Freshwater Biology 37(1):193-208.

Mc Dowall, M.C. 2000. Biogeography of the southern cooltemperate galaxioid fishes: evidence from metazoan macroparasite faunas. Journal of Biogeography 27:12211229.

Montgomery, D.R. \& Buffington, J.M. 1997. Channel-reach morphology in mountain drainage basins. Geological Society of America Bulletin 109:596-611.

Munné, A., Sola, C. \& Prat, N. 1998. QBR: Un índice rápido para la evaluación de la calidad de los ecosistemas de ribera. Tecnología del Agua 175:20-37.

Munné, A., Prat, N., Sola, C., Bonada, N. \& Rieradevall, M. 2003. A simple field method for assessing the ecological quality of riparian habitat in rivers and streams. QBR index. Aquatic Conservation: Marine and Freshwater Ecosystems 13:147-164.

Noble, R., Cowx, I.G., Goffaux, D. \& Kestemont, P. 2007.
Assessing the health of European rivers using functional ecological guilds of fish communities: standarising species classification and approaches to metric selection. Fisheries Management and Ecology 14:381-392.

Omernik, J. \& Bailey, R. 1997. Distinguish between watersheds and ecoregions. Journal of the American Water Resources Association. 33 (5):935-949.

Ortíz, J.C. \& Díaz-PÁez, H. 2006. Estado de conocimiento de los anfibios de Chile. Gayana 70(1):114-121.

Palma, A. \& Figueroa, R. 2009. Evaluación de ribera y hábitat fluvial a través de los índices QBR e IHF. Gayana. 73(1):57-63.

Parada, E. \& Peredo, S. 2005. La relocalización como una herramienta de conservación y manejo de la biodiversidad. Lecciones aprendidas con Diplodon chilensis (Gray 1828)(Bivalvia:Hyriidae). Gayana 69(1):41-47.

Parada, E. \& Peredo, S. 2006. Estado de conocimiento de los bivalvos dulceacuícolas de Chile. Gayana 70(1):82-87.

Peredo, S., Parada, E., Valdebenito, I. \& Peredo, M. 2005. Relocation of the freshwater mussel Diplodon chilensis (Hyriidae) as a strategy for its conservation and management. Journal Molluscan Studies 71:195-198.

Peredo, S., Parada, E., Valdebenito, I. \& Peredo, M. 2006. Effect of aerial exposure on physiological condition and survival of Diplodon chilensis (Hyriidae) during translocation. Malacologia 49(1):217-221.

Peredo-Parada, M., Martínez-Capel, F., Garófano-Gómez, V., Atenas, M. \& Riestra, F. 2009. Base de datos ecohidrológica de los ríos de Chile: una herramienta de gestión para los ecosistemas acuáticos. Gayana 73(1):119-129.

Peredo-Parada, M., Martínez-Capel, F., Alcaraz, J.D. \& BARgAY, M. 2009 Potential geographical distribution of two endemic freshwater fishes ( $P$. gillissi and $D$. camposensis) of Chile. En: Proceedings of the International Symposium on Ecohydraulics. ISBN: 978-981-08-2100. (Eds. International Association of Hydraulic Engineering and Research (IAHR) and Universidad de Concepción), Concepción. Chile.

Pérez-Losada, M., Jara, C.G., Bond-Buckup, G. \& Crandall, K.A. 2002. Conservation phylogenetics of chilean freshwater crabs Aegla (Anomura,Aeglidae): assigning priorities for aquatic habitat protection. Biological Conservation 105:345-353.

Rutllant, J. 2004 Aspectos de la circulación atmosférica de gran escala asociada al ciclo ENOS 1997-1999 y sus consecuencias en el régimen de precipitación en Chile central. En: El niño-La niña 1997-2000: sus efectos en Chile (Eds: Avaria, S., Carrasco, J., Rutllant, J. \& Yáñez E.). CONA, Chile, Valparaíso:61-76.

Stiva, L. \& Dudley, D. 2001. Buffer Zone versus Whole Catchment Approaches to Studying Land Use Impact on River Water Quality. Water Research 35(14):3462-3472.

SNelder, T. \& Biggs, B. 2002. Multiscale River Enviroment Classification for Water Resources Management. American Water Resources Association 38(5):1225-1239.

Snelder, T., Cattaneo, F., Suren, A. \& Biggs, B. 2004. Is the River Environment Classification an improved landscape-scale classification of rivers? Journal of the North American Benthological Society. 23(3):580-589.

Snelder, T., Biggs, B. \& Woods, R. 2005. Improved Eco- 
Hydrological Classificaction of Rivers. River Research and Applications. 21:609-628.

Schmutz, S., Cowx, I.G., Haidvogl, G. \& Pont, D. 2007. Fishbased methods for assessing European running waters: a synthesis. Fisheries Management and Ecology 14:369380.

VAldovinos, C. 2006. Estado de conocimiento de los gastrópodos dulceacuícolas de Chile. Gayana 70(1):88-95.

Vannote, R.L., Minshall, G.W., Cummins, K.W., Sedell, J.R. \& Cushing, C.E. 1980. The River Continuum Concept. Canadian Journal of Fisheries and Aquatic Science. $37: 130-137$.

Vera, A. \& Camousseight, A. 2006. Estado de conocimiento de los plecópteros de Chile. Gayana 70(1):57-64.

VILA, I. \& Molina, X. 2006. Variables químicas y biológicas.
En: Manual de Calidad del Agua. Servicio Agrícola y Ganadero. (Eds. Molina X. \& Vila, I.). Santiago 106 pp.

Vila, I., Pardo, R., Dyer, B. \& Habit, E. 2006. Peces límnicos: Diversidad, origen y estado de conservación. En: Macrófitas y vertebrados de los sistemas límnicos de Chile (Eds. Vila, I., Veloso, A., Schlater, R. \& Ramírez, C.), pp. 73-103. Editorial Universitaria, Santiago, Chile.

Villagrán, C. \& Hinojosa, L.F. 2005. Esquema biogeográfico de Chile. En: Regionalización Biogeográfica en Iberoámeríca y tópicos afines (Eds. Llorente, J. \& Morrone, J. J.) 551577 pp. Ediciones de la Universidad Nacional Autónoma de México, Jiménez Editores, México.

Winterbourn, M.J., Rounick, J.S. \& Cowie, B. 1981. Are New Zealand stream ecosystems really different? New Zealand Journal of Marine and Freshwater Research 15:321-328.

Recibido: 05.10.10

Aceptado: 02.11.10 